\title{
VAD SÖKER BESÖKAREN I MUSEET? MASSMEDIALA ASPEKTER PA MUSEIVÄSENDET
}

\author{
Heiner Treinen
}

Heiner Treinen ser kommunikationsproblemet $i$ museerna särskilt ur besökarens synpunkt. I sina omfattande, i Tyskland ofta äberopade, publikstudier bygger han sin analys av besökarbeteenden på jämförelser med resultaten av forskningen kring hur massmediebudskap, särskilt TV-program "konsumeras» och därvid anammas eller avvisas.

\section{$I$}

Just nu förefaller man i museernas utåtriktade verksamhet arbeta under ovanligt gynnsamma betingelser. Den snabba ökningen av antalet museer, det stigande intresset i massmedierna för kulturhistoriska samlingar och objekt, besökstalens ojämförligt snabba växt - allt detta ger intryck av att det finns en bildningshunger i samhället, av att äntligen behovet av 'livslångt lärande' börjat göra sig gällande. Om det förhölle sig så: då skulle säkerligen ett ökat behov av museer visa sig. Upplevelsekvaliteten hos offentliga samlingar skulle bjuda på intryck av stark påverkanskraft; med hjälp av museipedagogers insatser skulle de till och med ge impulser till tänkesätt och handlingsberedskap av bestående karaktär. Dock finns redan nu tecken på en överkapacitet hos museiväsendet. När det senaste decenniets besökstal analyseras i fråga om storlek, typ och regional fördelning, framträder tendenser som snarare motsvarar antagandet om överkapacitet än om stigande behov.

Sammanfattningsvis låter sig, på grundval av vår kunskap om besöksutvecklingen, följande förhållanden fastställas och ges en konsistent tolkning. ${ }^{1}$

Uppgifterna om besökstal kommer från museiförvaltningarna, inte från oberoende mätningar. Detta innebär - om det nu finns trovärdiga grunder för att ange högre än lägre tal - att en benägenhet för att offentliggöra de högre ligger påfallande nära till hands (därför: om institutionen har flera, administrativt skilda avdelningar som besökaren passerar, multipliceras besökstalet som gäller för hela byggnaden).

Vid publikräkningen adderas besök, inte 
58 besökare. En ökning kan därför återföras mindre på att andelen besökare i befolkningen ökar än på att den traditionella museipubliken flitigare utnyttjar de museer som finns.

En faktisk publikökning åtnjuter i första hand stora internationellt kända museer, till övervägande delen belägna i världsstäder med hög resandefrekvens. Majoriteten av de existerande museerna - specialmuseerna och lokalmuseerna - upplever knappast någon ökning av besökarströmmen; här leder nya museiprojekt på grund av bristfälliga lönsamhetsberäkningar till mindre katastrofer, när det gäller driftkostnaderna, sedan museet väl uppförts och samlingar inköpts eller övertagits.

$\mathrm{Om}$ förutsättningarna för långvariga uppgångar i besökstalen för ett specialeller lokalmuseum analyseras, visar sig vanligtvis att huvudmannen - eller de anställda själva - tvingats till utomordentligt höga marginalkostnader för att vinna och behålla besökare utöver ett givet begränsat klientel. Sådana kostnader består i omfattande marknadsföring, i tids- och kostnadsintensiv programverksamhet eller i etablerandet av varaktigt samarbete med grupper och föreningar inom ett stort upptagningsområde.

Besökarpotentialen har under det senaste decenniet stabiliserats och bara marginellt varierat. Det finns nu, liksom tidigare, en hård kärna av icke-besökare, personer utan högre skolbildning och utan kvalificerad yrkesutbildning. Det rör sig om en tydlig majoritet av befolkningen som bara under extraordinära betingelser kan motiveras för ett museibesök, för att inte tala om återkommande sådana.

När det talas om besökspotential, vore det vidare förhastat med slutsatsen, att flertalet personer med förutsättningar mentalt och socialt - för att uppskatta museet som kulturell institution också verkligen skulle bli museibesökare. För potentiella museibesökare finns många alternativ när det gäller att utnyttja bildnings- eller kulturutbud med ett innehåll som motsvarar museets. Det som utom den 'ideella närheten' ytterligare krävs är en 'benägenhet för utomhusaktivitet'; det rör sig här om en motivationsfaktor som är oberoende av aktivitetens innehåll; det är frågan om en disposition som förvärvas tidigt och dessutom hänger samman med den fas av livscykeln som vederbörande befinner sig i. Även om befolkningsandelen av på detta sätt motiverade personer inte kan anges, kan dock på goda grunder antas, att mindre än hälften av den icke rörelsehindrade vuxenbefolkningen är benägen för utomhusaktiviteter, för att flitigt umgås med vänner och bekanta eller för att ta ett offentligt kulturutbud i anspråk.

När båda stämmer - dvs innehållsmässiga förutsättningar som dragningskraft i museet med tillräckligt stark motivation hos den enskilde för besök - då återstår ungefär 15 - 20 procent av en vuxen stadsbefolkning som realistisk beräkningsgrund för ett museum.

Därvid måste man också betänka, att denna befolkningsandel har starkt differentierade intressen och att därför de olika tillgängliga museerna inte kan räkna med att locka hela gruppen.

Dessutom tas med dessa förutsättningar inte med i beräkningen att återbesök är nödvändiga för att besökstalet ska kunna upprätthållas och därmed museets funktionsnivå. För att åstadkomma detta är avsevärda insatser nödvändiga - om inte 
historiska tillfälligheter eller ett fungerande image-skapande fortlöpande drar en mängd turister till museet.

Ett museums framgång i form av varaktiga höga besökstal är i första hand beroende av den fritidsrelaterade infrastrukturen i museets omland. En ytterligare förutsättning är att museet har rika samlingar med högt underhållningsvärde för ickefackmän, och att det därför blivit inte bara lokalt bekant.

\section{II}

Förmedlingen av ett museums innehåll, liksom tillväxten av museiutbudet, bygger på uppfattningar om besökarmotivation, besökarintresse, besökarbeteende och deras betydelse på sikt. De stödjer sig vidarepå museididaktikens och museipedagogikens möjligheter. Detta kan man redan avläsa i det språkbruk som slagit igenom som del av museipedagogernas identitetsskapande, när det talas om 'museiupplevelse', om 'estetisk träning i museet' och om museet som 'läromedel' och 'bildningsinstitution'.

Såvitt sådana fraser tjänar som målsättningsformulering är de oproblematiska även om de missar den verkliga betydelsen av museibesöken för huvudparten av publiken.

I det följande skall jag försöka visa att upplevelse- och bildningskvalitet som ambition hos de undervisningsansvariga i museerna resp. förväntan hos flertalet av besökarna otvivelaktigt är betydelsefulla faktorer, men att de hänger ihop på ett mycket tillfälligt sätt; och att båda, upplevelsen av museet och bildningsvinsten eller hellre den fördjupade bildningen bara skenbart har samband. Vanligtvis, vid det så att säga vardagliga museibesöket, finns inget samband mellan kunskapstillväxt och den faktiska museiupplevelsen.

Ett sådant generellt påstående överensstämmer med största sannolikhet dåligt med museipedagogernas erfarenheter åtminstone inte med de museilärares som har en trogen och uppskattande publik. Dock måste i sammanhanget framhållas som ofta när det gäller förhållandet mellan fackmän och lekmän - att urvalet av informanter merendels är ytterst selektivt. Därutöver måste man utgå från att - när det gäller lekmäns förhållande till ett bildningsstoff - ett visst mått av betygsättningsångest föreligger. I sådana situationer förhåller sig människor redan i förväg på ett sådant sätt att de försöker leva upp till de anspråk som de tycker sig möta; den mänskliga förmågan till empati, till att motsvara rollförväntningar och sociala krav träder i dagen. Följden blir att den egna tolkningen av besökssituationen, ja, $t$ o m egna känslor och reaktioner kontrolleras och förträngs - särskilt i umgänget med fackmän och kännare.

För att alltså blottlägga dessa systematiskt kontrollerade intentioner, faktiska upplevelser, förväntningar och beteenden hos besökare, är det nödvändigt att använda metoder som gör hållbara utsagor över sådana förhållanden möjliga (exempelvis: en kombination av iakttagelser i utställningsrummen, strukturerade intervjuer samt analyser av utställningarnas innehåll och didaktiska uppbyggnad). På detta sätt låter sig med utgångspunkt från slumpvisa stickprovsundersökningar och andra tillförlitliga urvalsmetoder ett gott underlag vinnas för tolkningen av besökarbeteenden och bakomliggande motiv.

Ett första, bara skenbart trivialt, faktum 
60 låter sig fastställas i nära nog alla undersökningar av besökarfrekvens och besökarbeteende: det finns ingen normalbesökare. Ensambesökare, par, skolklasser - de befinner sig i olikartade sociala situationer, de har skilda intressen och uppvisar följaktligen olikartat beteende. Detsamma gäller för publiksammansättningen, som i varje museum sannolikt har individuella särdrag. Denna publik bidrar genom sin närvaro till atmosfären och ger därmed skilda impulser och beteendeanvisningar åt andra besökare. ${ }^{2}$

Trots detta kan vissa regelbundenheter $\mathrm{i}$ beteende fastställas, som framträder när besökarna - som ju oftast är fallet - inte tas om hand av en museipedagog. Man är vid första blicken benägen att tala om ett enkelt stimulus-respons-mönster; dock innan detta mönster analyseras, skall vi bara tala om 'konstanter' som gäller för museibeteende. Därefter återstår att visa hur orsakerna till det faktiska uppträdandet $\mathrm{i}$ museet inte går att återföra på ett enhetligt motivationsmönster. Det finns grund för antagandet, att - vid sidan av de förhållningssätt som suggereras av tingen och det sätt varpå de presenteras (något som kunde kallas 'ting-tvånget') - ett sökande efter en specifik underhållning, liksom även (och detta i särskilt hög grad) normativa faktorer, är verksamma.

\section{1}

De Regler för museibesökaren som en borgerlig älskare av de sköna konsterna i början av 1700-talet formulerade i en (på eget initiativ sammanställd) vägvisare till tyska museer har mer än kuriositetsintresse. ${ }^{3}$

Reglerna skall - helt i tidens rationalistiska anda - tjäna till besökarens 'nytta och fromma'. Till nytta eftersom de syftar till att museets intendenter ska uppfatta besökaren som kännare och därför behandla honom på ett tillmötesgående sätt. Till fromma eftersom besökaren, om reglerna iakttas, ska kunna öka sin bildning så att den går att briljera med i de dåtida salongerna.

Reglerna förutsätter att det råder ett asymmetriskt förhållande mellan intendenten som fackman och besökaren som lekman, samt att besökaren måste ge intryck av att vara kännare för att få del av intendentens kunskaper.

Sådana situationer är inte ovanliga. De inträffar överallt där någon upplever en diskrepans mellan de förväntningar som möter och den egna kompetensen. Vid sådana tillfällen känner man oro för att nedvärderas av sin interaktionspartner. Detta, liksom följderna därav, vill vi alla undvika.

Uppförandereglerna formulerades för den situation som rådde vid århundradeskiftet $\mathrm{i}$ offentliga samlingar och salonger - åtminstone vad beträffar lämpligheten av att hålla fackmannen i ovisshet om de egna kunskapsluckorna.

Den som besöker ett museum bör välja kläder som anstår en uppåtsträvande 'literatus' (intellektuell, som tillhör den växande gruppen av litteratörer etc), inte pråligt, men inte heller torftigt. Då, nämligen, kommer intendenten att betrakta dig som en jämbördig och låta dig se de inlåsta dyrbarheter, som ingår i samlingarna. Samma syfte gäller för uppförandet under rundvandringen i utställningssalarna: stanna inte alltför länge framför ett föremål som intresserar dig; det kan ju tänkas att detta föremål i fackmäns och kännares ögon inte är särskilt intressant! 
Och följdriktigt gäller omvändningen: ser du i samlingen något obetydligt föremål, gå inte likgiltigt förbi det, utan dröj en stund, ty, skulle det råka vara ett viktigt föremål och intendenten skulle ertappa dig med att inte uppmärksamma detta, skulle ditt anseende sjunka och du omedelbart räknas till de okunniga som inte är värda artigt bemötande.

\section{2}

Ett iakttagbart genomsnittligt besökarbeteende förefaller idag följa samma regler. ${ }^{4}$ Uppehållet framför varje enskilt objekt är utomordentligt kort; det finns en tendens att samtliga avdelningar och objekt besiktigas; egen kunskap och egna erfarenheter inför det utställda behåller besökaren för sig själv; frågor är sällsynta också om expertis finns till förfogande; kritik mot utställningsarrangemang, didaktik och texter framförs inte; öppet uttalar besökarna i museet endast uppskattande omdömen. Kort sagt - under den tid som förflutit från 1700-talet förefaller besökarnas grundsituation knappast ha förändrats.

$\mathrm{Nu}$ som tidigare gäller asymmetrin i förhållandet mellan besökare och de anspråk som utställningarna ställer. Besökaren behärskar - i sin egen föreställning - inte alls eller bara till ringa del de kunskaper som finns om tingen; samlingarnas vetenskapliga kvalitet ställer höga bildningskrav! De museala objektens värde bygger på specialistkunskaper relaterade till slutna vetenskapliga och skenbart objektiva diskurser, inför vilka besökaren har att ödmjukt böja sig. På motsvarande sätt tillmäts besökarens egen värdering ingen objektiv karaktär och är utan intresse.

Alla dessa sätt att reagera och att upple- va en situation som kan iakttas hos museiexperimentalpsykologer kallar evaluation apprehension; en ambivalent situation i vilken medvetandet om egna värderingar och önskedrömmar kolliderar med risken för att ådra sig missaktning eller åtminstone lägre uppskattning från personer som man själv hyser respekt för. ${ }^{5}$

Vad som än sägs om 'tröskelångest' inför ett museibesök och om ovana vid museimiljön - grunden också för skenbart obesvärade besökares beteende utgörs nästan undantagslöst av oron för att genom olämpligt uppförande löpa risken att förlora $\mathrm{i}$ anseende hos andra närvarande. Museer är i besökarens ögon tillhåll för kulturspecialister. I sociologiskt språkbruk handlar det om att de symboliskt ockuperat ett offentligt rum och därmed bestämmer över beteende- och handlingsmöjligheter. Dessa utgör en begränsande struktur som med en engelsk term brukar kallas behaviour setting. Därmed menas att konstruktionen av ett inre eller yttre rum både innebär inbjudan till bestämda typer av interaktion och riktar bestämda förväntningar på uppförande hos dem som vill använda rummet. 'Museibesöket' representerar i så måtto en social konstant.

\section{II.3}

Underlag för detta bildar inte erfarenheten av ett enda museum eller en enda museityp utan själva inrättningen, institutionen museum. Som sociologiskt begrepp betecknar institution ett avgränsbart fält av normer och möjliga beteenden, som är relaterade till bestämda verklighetssektorer och möjliggör socialt handlande och kommunikation. För institutionen museum gäller 
62 det en strukturering av det offentliga samlandet (resp. överförandet av samlingar till offentligheten) av objekt, som gäller eller uppges gälla som betydelsebärare, och av sammanhang mellan dessa objekt. ${ }^{6}$

I överensstämmelse med den västliga kulturkretsens rationalistiska verklighetsuppfattning försöker man - med framgång - formulera en vetenskaplig motivering för att samla och utställa objekt. Detta innebär när det gäller den allestädes närvarande vetenskapligheten, att grunden för det offentliga samlingsväsendet består i taxonomier, alltså i klassifikationssystem med universella anspråk. Dessa kan bestå i kategorier som är tillämpliga på skeenden och företeelser i naturen (exempelvis geologins och biologins taxonomier), på teknik och teknologi (exempelvis trafik, ångmaskiner osv), på kultur (tid-rumsliga epoker) eller på konst (stil, stilskillnader osv) ${ }^{7}$

Klassificeringen av objekt efter rationella och vetenskapliga kriterier får en rad oavsiktliga konsekvenser.

Taxonomiskt ordnade samlingar är aldrig fullständiga; de insamlade objekten hänvisar till andra som inte finns i samlingen. Samtidigt uppstår en tävlan om objektens kvalitet och om samlingarnas grad av fullständighet, vilken då vilar på objektiva kriterier. Detta har för museibesökaren som följd, att enbart ett intresse för objekten inte är tillräckligt för att 'förstå' samlingen. Till intresset måste 'vetande' läggas, nämligen en kunskap om taxonomins kategorier och deras betydelser. Men sådan kunskap kan man inte komma åt enbart genom betraktande, utan först genom kognitiva insikter i relevanta discipliner.

Av denna anledning är den för objektens uppskattning erforderliga, på kunskap grundade empatin följaktligen att finna hos människor med viss skolbildning; hos befolkningsgrupper utan sådana förkunskaper måste alldeles särskilda förutsättningar föreligga för att de skall kunna uppskatta museernas samlingar. Bourdieu har kallat detta 'förmåga till dekodifiering av objekt'; i själva verket handlar det i de offentliga samlingarna om en förmåga till tolkning av ytterst specifika, universella klassifikatoriska principer. Det rör sig därvid inte om kreativitet, inte heller om inlevelseförmåga, utan om en särskild sorts kunskaper, alltså om skolbildning. ${ }^{8}$

Ytterligare en följd av vetenskapligheten är den omständigheten, att huvudparten av alla kulturhistoriska objekt inte kan hänföras till en enda samlingskategori. Samma objekt uppträder ofta under skilda taxonomiska rubriker, tillförs alltså skilda områden av mänskligt vetande. Skälet är uppenbart: om än varje objekt i en samling synbarligen framträder som en helhet, så ges det i utställningen en legitimation endast tack vare en eller ett par som allmängiltiga uppfattade egenskaper och kännetecken. En neolitisk Venus-figur kan sålunda motivera sin placering såväl i samlingar av förhistoria, kultur- eller konsthistoria som i lokala och regionala museer.

Oberoende av detta klassificerings- och tillhörighetsproblem är ändå det potentiella upplevelsevärdet av museibesök alltid mera omfattande, mera okontrollerat, ja okontrollerbart, än de överväganden som bestämt vederbörande objekts insamlande och utställande,

När det gäller upplevelsekvaliteter följer på grund härav att samlingar bara undantagsvis bearbetas och presenteras pedagogiskt så att de kan inordnas i vardagsrele- 
vanta kontexter eller i vardagen bekanta objektsammanhang. ${ }^{9}$

\section{III}

Den vanliga besökarens uppförande i museet förefaller, nu som då, följa rekommendationerna för vår 'literatus' från 1700-talet. Ett frapperande kort betraktande av varje utställt objekt kombinerat med ambitionen att se alla utställningar.

Visserligen finns ett positivt samband mellan besökarens bildningsgrad och betraktandetiden (alltså: ju fler skolår desto längre tid framför de enskilda tingen), men den i våra undersökningar uppmätta tiden för välutbildade besökare motsvarar ändå långtifrån den tid som skulle behövas för att förstå eller ens uppfatta de didaktiska avsikterna; inte ens de till objekten anslutna texterna kan med uppmärksamhet läsas under den korta tid som ägnas varje ting. En verkan jämförbar med den som uppnås $\mathrm{i}$ en normal inlärningssituation är under sådana omständigheter inte att vänta. Dock anser jag mig kunna visa att utställningar kan påverka, om än inte på det sätt som anhängarna av ett inlärningsprogram önskar. För att säga det utan omsvep: den traditionella misstro mot turistiska besökare som möter hos musèifolk förefaller få näring och stöd i våra iakttagelser.

En ytlig tolkning av undersökningarnas data tycks ge vid handen att besöken snarare motiveras av nyfikenhet och förströelsebehov än av sakligt intresse för ämnet, för att inte tala om av kunskapssökande eller bildningstörst.

En sådan tolkning av besökarnas förhållningssätt är ingalunda överdriven; den underbyggs av kompletterande data.
Systematiska iakttagelser över en längre tidsperiod i olika avdelningar av ett tekniskt/naturvetenskapligt museum visar, att besökarna framför allt reagerar med intresse på avbrott $\mathrm{i}$ vanda eller väntade utställningsanordningar. En ljudkälla i ett annars tyst rum drar omedelbart uppmärksamheten till sig; likaså väcker också mycket enkla manipulationsmöjligheter överdrivet intresse. Att det därvid rör sig om ett intresse som inte primärt gäller saken eller företeelsen făr den museipersonal som måste se till dessa automatiserade fysikaliska eller kemiska experiment nogsamt erfara. De av våra egna iakttagelser bekräftade uppgifterna visar eftertryckligt att - sedan man tryckt på knappar eller manövrerat spakar - resultaten i form av de processer som utlösts inte inväntas innan man uppsöker någon annan del av utställningen. För sådana besökare är alltså just aktiviteten betydelsefull och eftersträvad; läroprocesser och inblickar i obekanta sammanhang är av andrahandsintresse, om sådana möjligheter överhuvudtaget föresvävar vederbörande. ${ }^{10}$ Sådana resultat låter i förstone förödande - framför allt i öronen på kulturansvariga som intresserar sig för museet som bildningsinstitution och för museipedagogik: kortvarigt tittande på det som är utställt, snabb promenad genom så många salar och utställningar som möjligt, de iögonenfallande arrangemangens överdrivna lockelse - och därtill de påtagligt frånvarande besökargrupper som, enligt kulturadministratörernas uppfattning, bäst skulle behöva den direkta kontakten med konst, kultur- och naturhistoria, teknik och vetenskap. I denna situation blir offentliga samlingars funktioner så oklara, eller åtminstone diffusa, att museernas bildningsupp- 
HEINER TREINEN

64 gift utan tillsatser av museipedagogisk verksamhet ter sig tämligen meningslös.

\section{IV}

Innebörden i det syndrom av beteenden, känsloreaktioner, förväntningar och motiv som möter hos museibesökaren kan lättare tolkas, om man studerar motsvarigheter utanför det begränsade kulturområdet.

Faktiskt kan man finna ett identiskt syndrom, oberoende av de skilda innehållen i de utomordentligt skiftande situationer som kännetecknar människors fritid, alldeles särskilt $\mathrm{i}$ beteendet hos dem som utsätter sig för massmediers påverkan (bara annorlunda i motoriskt hänseende). ${ }^{11}$ Också inför TV-n dominerar nyfikenhet och förströelsebehov; inte heller här kan man tala om inlärningseffekter (vare sig man värderar dem negativt eller positivt), vilket alla seriösa långtidsundersökningar av televisionens påverkan visat. ${ }^{12}$

Det gemensamma i masskommunikationsbeteendet kan beskrivas som ett 'aktivt dåsande'. Den dåsande ägnar sig åt ett riktat dagdrömmeri - ett beteende som dock på intet sätt uppvisar passivitet, idébrist, verklighetsflykt eller liknande. Tvärtom: det aktiva i dåsandet består just i ett sökande efter varaktiga impulser och att förstärka dem. Den eftersträvade expressiva stimulansen har emellertid en problematisk egenskap som underhållning: den blir fort utnött och förlorar därmed sin verkan som angenäm ändamålslös andlig stimulering. Av det skälet måste den hela tiden avlösas av nya stimulanser för att man skall kunna bibehålla det önskade emotionella spänningstillståndet. Ordet 'förströelse' sammanfattar på ett pregnantare sätt än det formella 'fritidsbeteende' innehållet i detta ansvarslösa och konsekvenslösa handlande.

Härur förklaras för övrigt också det typiska förhållningssättet framför TVskärmen, som - mindre för kulturkritiker än för 'TV's marknadsförare och producenter - är ett förargligt problem: tittaren följer sällan ett helt program utan växlar oupphörligt med fjärrkontrollens hjälp mellan tillgängliga kanaler. På samma sätt avbryter prat med vänner och anhöriga eller sysslandet med de mest olikartade ting koncentrationen under den $s \mathrm{k}$ TVkonsumtionen. Exakt samma sorts beteende, samma 'aktiva dåsande', kan iakttas hos den vanliga museibesökaren - ett beteende som för museifolket (i synnerhet museernas didaktiker och pedagoger) måste framstå som särskilt kränkande, därför att vetenskapligheten inte tas på allvar.

När en besökare rör sig i ett museum och inte hänvisas till en bestämd plats, framträder det aktiva dåsandet hos de flesta i form av det välbekanta uppträdande vi alla praktiserar under stadspromenader och som kunde kallas 'kulturell windowshopping'. När museerna fungerar som massmedier, förhåller sig besökarna på motsvarande sätt (och med förutsägbar sannolikhet var och en av oss i samma situationer): vi dröjer framför allt inför sådant som vi redan på förhand - alltså före museibesöket - har någon bekantskap med. Såvitt vi har någon sorts kunskap om de föremålskategorier vi möter och deras sammanhang, räcker kanske ett ögonkast för att notera ett igenkännande, väcka en association, komplettera en kunskap. Allt annat går spårlöst förbi som en sorts visuell utfyllnad.

En analys som denna av det psyko-fysis- 
ka förloppet i ett museibesök erbjuder ett problematiskt stoff för diskussionen om de möjligheter som museipedagogen förfogar över för att stimulera besökaren till att ta del i en bildningsupplevelse, att göra museet som sådant till en upplevelse eller rentav en bildningsinstitution.

Museibesöket är betingat av en rad inbördes oavhängiga faktorer. Först och främst ett redan befintligt internaliserat, alltså under lång tid konstituerat, system av referenser med vars hjälp hittills obekanta objekt identifieras, ordnas och bearbetas. Föreligger en sådan beredskap, finns förutsättningen för empati inför särskilda samlingar och man gillar självklart museer, där sådana finns.

Detta betyder dock ingalunda att dessa museer blir uppsökta. Därtill krävs som komplettering ett intresse och en beredskap för utomhusverksamheter; saknas detta så förblir museibesök sällsynta; det särskilda sakintresset tillgodoses med hjälp av andra visuella medier.

Det är numera (och kunskapsteoretiskt relativt väl säkerställt) möjligt att fastställa hur de kunskapsrelaterade processerna under ett 'aktivt dåsande' eller 'kulturell window-shopping' ser ut. Inlärnings- och perceptionspsykologer vet att sinnesförnimmelser via sensorisk strukturering överförs i närminnet. Varaktiga minnen kan överhuvudtaget inte uppstå förrän de aktuella sinnesintrycken återkopplas till långtidsminnets innehåll, dvs när bearbetnings- och associationskoder står till förfogande, med vars hjälp sensoriska varseblivningsinnehåll kan organiseras semantiskt.

Uttryckt i vardagsspråk: underhållning och förströelse kan bara de finna som redan före sitt museibesök förfogar över kriterier för att bearbeta det de ser. Vidare: medan huvudparten av det man får se lätt glöms bort, blir det man redan lagrat i sitt minne ytterligare förstärkt. I normalfallet, så lyder följdsatsen, lär man sig genom massmedierna ingenting nytt utan uppfattar bara sådant som bestyrker den redan befintliga kunskapen, alltså 'lär' man sig kanske något helt felaktigt eller inte avsett.

Det kännetecknande för massmedier och deras delvis oväntade verkningar består i en alldeles speciell struktur för hur symboliska innehåll kommuniceras och till vem. Till skillnad från alla andra kommunikationsformer, riktas massmedierna till heterogena grupper av människor som inte kommunicerar direkt sinsemellan. Massmedierna riktar sig inte till en enskild person och inte till strukturerade gruppers eller organisationers specifika karakteristika, utan till stora grupper. Därför är kommunikationen ensidig och asymmetrisk; deltagaren är visserligen inte dömd till passivitet, men väl till att inte ha något direkt inflytande över kommunikationens innehåll eller form och framför allt till att inte kunna svara medierepresentanterna med en egen diskurs. Just dessa egenskaper har museisamlingarna i förhållande till besökarna. Museerna bestämmer över kommunikationsformen och över begränsningarna när det gäller att erbjuda bildning, vetande och kunskaputveckling åtminstone för majoriteten av publiken. Slutsatsen av de framlagda resultaten och deras tolkning hänför sig till det redan sagda, nämligen att de eventuella bildningsfunktionerna i enstaka eller upprepade museibesök är avhängiga av den förhandskunskap besökarna har.

Ur dessa iakttagelser - ursprungligen giltiga för televisionens påverkan - utveck- 
66 lades det $s \mathrm{k}$ knowledge-gap-teoremet, ett teorem som möjligen också kan gälla museet. ${ }^{13}$

De ursprungliga forskningsresultaten hänför sig till jämförande undersökningar av politiska insikter. Dessa visade under loppet av 10 till 20 år följande. En första mätning speglar ett redan välkänt förhållande, nämligen att en stor del av USA's befolkning visar bristfällig kunskap om händelser, strukturer och personer på den politiska scenen såväl inom som utanför USA. De politiskt välinformerade representerar en relativt liten andel av befolkningen. Senare mätningar ger samma bild - dock med ett tillägg: gapet mellan de välinformerade och de okunniga har ökat. De 'bildade' uppvisade ökade insikter, de dåligt informerade ännu sämre kunskaper.

Förklaringen till den avtagande politiska kunskapen i den breda befolkningen och den samtidiga tillväxten hos de fä förklaras med att den politiska informationen under mellantiden alltmer kommit att hämtas via det visuella mediet - televisionen. Egenarten hos en övervägande visuellt kommunicerad information består enligt en (kanske överdriven) tolkning, i att tittaren ges en bedräglig känsla av att omedelbart förstå den avbildade situationen också när informationen avser förhållanden som dittills varit obekanta. En följd av detta är att man inte tycker sig sakna information; detta missförstånd leder till att behovet av ett problemorienterat sökande efter bakgrundskunskap inte alls uppkommer; på detta sätt förvandlas information till underhållning. För dem som från sin barn- och ungdom utrustats med en solid grund av kognitiv bearbetningsförmåga, erbjuder däremot konsumtionen av visuella medier otaliga - medve- tet eller oavsiktligt förmedlade - möjligheter till att förvärva ytterligare insikter, mera vetande och erfarenheter.

Om vi nu tillämpar denna insikt om en växande kunskapsklyfta och dess följdverkningar på museerna, kan först konstateras att det rör sig om en variation på det gamla temat 'massa och elit', men då inte om en maktelit utan om en bildningselit.

Faktiskt handlar det, när det gäller sambandet mellan mediekonsumtion, museibesök och bildning, om följande: redan en ungdomspublik med längre skolgång sysselsätter sig hellre med tryckta medier än med radio och television, för att söka information inom ett brett ämnesspektrum. Elektroniska massmedier som radio och television favoriseras mera av bildningsmässigt handikappade ungdomar. Vi vet också att frivilliga museibesök (alltså inte skolbesök) korrelerar med ett större intresse för läsmedier.

Användningen av läsmedier avhänger av bildningsnivån, användningen av television (med undantag av kulturprogram) är vanlig på alla bildningsnivåer. Inte medieinnehållen, utan själva medierna, väljs bildningsspecifikt.

Undersökningar av förhållningssättet till medier och användningen av medier pekar på ett komplext sammanhang mellan förhandskunskaper och medieanvändning i informations- och bildningssyften. Redan i tidiga år börjar en differentiering efter intressen och kognitiv inriktning. Huvudförmedlare av kognitiv orientering och kulturella intressen är nu som tidigare skolsystemet med sin överdrivet starka betoning av skriftkulturen och de därmed förbundna teoretiska/rationella innehållen. Särskilt framgångsrik är denna formella bildning som socialisationsmedium 
när familjen och kretsen av jämnåriga vänner har en motsvarande bildningsbakgrund. I motsats härtill avtecknar sig den majoritet av människor utan högre skolutbildning, vilkas intresse för form och innehåll i skriftkulturen är obetydligt, liksom därur härledda intressen för högkulturella symboler. Deras handlande orienterar sig - förenklat uttryckt - snarare mot traditionella än rationella mönster och snarare mot en kommunikation av kunskap och information genom direktkontakter än via massmedier.

Människor med dessa karakteristika är senare $\mathrm{i}$ livet benägna att undvika kognitiva och med 'bildning' associerade medieinnehåll; att snarare tillgripa bild- än läsmedier; och på motsvarande sätt vara mindre välinformerade - om det inte gäller den egna sociala kretsen och om traditionell, personligt förmedlad kunskap om samhällsförhållanden. ${ }^{14}$

Informationer om samtidsskeendet liksom grundligare kunskap om andra områden blir relevanta för befolkningsflertalet först då de får en framträdande plats i allmänna opinionen. I sådana fall minskas avståndet i kunskapsomfång mellan den bildade och de företrädesvis traditionellt orienterade. Växande kunskapsluckor kan däremot fastställas när det gäller områden som inte är aktuella i den offentliga debatten, men kan vara betydelsefulla för intellektuella och vetenskapsmän. Ju starkare museers innehåll kan bli identifierade som symboler i en lokal befolknings offentlighet, desto mer blir de till 'sevärdheter', desto mindre kanske till symboliska element för en intellektuell publik. I en sevärdhet av detta slag brukar besöken emellertid bli talrikare.

Tillämpad på offentliga samlingar blir slutsatsen överraskande nog, att snarare det bekanta än det obekanta tilldrar sig uppmärksamhet och att bekräftelsen av en kunskap i stället för dess tillväxt har den största betydelsen för den vanliga människans kulturella hushållning under den dagliga rutinens förströelsefas. Just när museipedagogiska program skall läggas upp för en publik är det viktigt att inte bara rikta in sig på enstaka delmål, utan att så långt som möjligt ta hänsyn till människors hela sociala kontext. Det går då att få en realistisk uppfattning om vad besökarna på förhand känner till och vilka utsikter det finns för att tillföra nya insikter.

Massmedialt förmedlade innehåll (alltså också utställningsinnehåll) kan få en relativt självständigt kunskapsvidgande eller på annat sätt inflytelserik verkan för de personer som i sociala nätverk möter likasinnade. Deras sammanfallande intressen kan förstärka resp. medieinnehåll. Detta motsvarar det väl underbyggda teoremet om two-step flow of communication liksom den betydelse som opinionsbildare har i sociala nätverk vid avvisandet eller acceptansen av massmedialt förmedlade innehåll. ${ }^{15}$

Båda teoremen visar att massmedialt spridda informationer och attityder bara har en chans att bli trodda och anammade om dessa samtidigt diskuteras i vederbörandes umgänge och överensstämmer med den där rådande meningen. Uppstår en avvikelse mellan medieinnehåll och gruppövertygelse uppkommer alltid en omtolkning av medieinnehållet $\mathrm{i}$ enlighet med den förhärskande meningen och övertygelsen i den egna gruppen och hos dess företrädare. ${ }^{16}$ 
Den som på allvar vill tillämpa begreppet 'livslångt lärande' i museiarbetet, alltså inte bara vill främja erinringsvärdet $i$ ett museibesök, utan också skapa grunden för en mera djupgående förståelse av samlingarna, bör erinra sig följande grundläggande förutsättningar för, i egentlig mening, pedagogiska, socialiserande lärprocesser:

- de som deltar i en socialisationsprocess måste stå i ömsesidig växelverkan;

- den socialiserande relationen måste bli varaktig, dvs den måste äga rum över en längre tid och upprepas med regelbundenhet och med samma personer som aktörer;

- relationen måste ha en bestämd struktur, dvs en självklar.auktoritetsroll eller ledarroll måste ha etablerats, vars innehavare kan utöva socialt tryck, alltså förfoga över möjligheter till social kontroll av positivt slag;

- en återkoppling av förmedlade innehåll måste kunna äga rum. Därmed menas att förmedlaren omedelbart reagerar på förändringar i socialt, psykologiskt och kognitivt hänseende hos deltagarna i läroprocessen (och vice versa: de i processen inbegripna personerna måste också kunna påverka de institutionella förutsättningarna);

- läroprocessen måste ha definierade mål; det får inte handla om ett program med diffusa underhållningssyften.

De nämnda elementen bildar förutsättningen för att en objektförståelse och ett självständigt 'livslångt lärande' skall kunna etableras. ${ }^{17}$

Museipedagogernas dilemma är därvid mer komplicerat än det ser ut vid första anblicken.
Ensamma och för sig har museipedagogerna knappast möjlighet att organisera sådana på långsiktigt bildningsarbete inriktade grupper; det skulle i så fall vara i folkhögskolor eller i fackligt eller andra politiskt verksamma basorganisationer. Att ansluta till skolans läroplaner, särskilt de förgymnasiala, skulle kunna erbjuda ett första steg i en möjlig anslutning till formaliserade lärogångar. I själva museet kan bara i undantagsfall och då i museer med i samhällsarbete starkt engagerad personal sådana varaktiga studieverksamheter etableras - mest därför kanske att med största sannolikhet besökarna själva representerar det svåraste hindret. Bara en försvinnande minoritet skulle vilja utsätta sig för den sortens studium och då företrädesvis människor med ovanliga psykiska och sociala egenskaper, och detta likaså säkert bara i undantagsfall.

En sådan slutsats kan vi dra ur de redan anförda undersökningsresultaten. Besökare kommer för ett kort besök, väntar sig symbolisk/kulturell underhållning och förströelse av upphöjt slag, är inställda på sinnesupplevelser - och framför allt: en stor del av dem vill upprätthålla en garanterad anonymitet $\mathrm{i}$ förhållande till medbesökare och museipersonal. Social distans är ingen olycka för urbana människor, utan en eftersträvad frizon, som gör det möjligt, för människor med helt olikartade och konkurrerande intentioner, att konfliktfritt umgås med varandra. ${ }^{18}$ Och till detta hör att hålla sig utanför indoktrineringsförsök och bildningsprogram detta är åter identiskt med förhandsinställningen till massmedial påverkan.

Det föreligger disparata erfarenheter med bildningspolitiska försök i samband med museiväsendet. Sålunda har det talats 
om folkbildningsinitiativ i början av 1900-talet och om erfarenheter av likartade program i DDR. I stora utvecklingsplaner för livslångt lärande på väg mot förverkligandet av den kulturmedvetna socialistiska människan gavs en framträdande plats åt lokalmuseer under 1950-talet. Just deras lokala förankring skulle erbjuda förutsättningar för en varaktig interaktion mellan kommuninvånarna med hjälp av museiledarens initiativ och koordination. Grupper och kollektiv skulle stödjas; likaså museerna som platser för möten och förmedlare av kultur- och naturinnehåll planer som ingalunda hade sitt ursprung enbart i partifunktionärernas stalinistiska indoktrineringsvilja. ${ }^{19}$ Spranger hade i Bildungswert der Heimatskunde (hembygdskunskapens bildningsvärde) förfäktat liknande tankar; före honom ville Alfred Lichtwark, som hade observerat museibesökarnas passiva tittande, i direkt dialog med sin publik stimulera till bildningsupplevelser. ${ }^{20}$

Alla strävanden av detta slag, såväl de tidiga folkbildningsansatserna som de hembygdsrelaterade försöken i DDR, kan p g a sin ringa verkan anses förfelade. Framgångsrika däremot har de ansatser alltid varit - och är så än idag - då enstaka karismatiska museiledare lyckas inleda ett fortgående samtal med det omgivande samhället och kan arbeta med ett troget klientel, vars medlemmar fungerar som 'multiplikatorer' (i marknadsföringsmening) och i längden vidgar museets samhällsroll. Detta lyckas särskilt när museet och framför allt dess ledare inte bara följer gängse regler utan skapar nya överraskande former för sitt arbete.
Uppsatsen Was sucht der Besucher im Museum finns tryckt i: Gottfried Fliedl $(\mathrm{Hg})$, Museum als soziales Gedächtnis? Kritische Beiträge zu Museumswissenschaft und Museumspädagogik. Klagenfurt 1988. s. 24-41. Övers. P-U Ågren.

\section{NOTER}

1. Jfr B. Graf: Besucherbezogene

Museumsforschung zwischen Anspruch und Wirklichkeit. Museumskunde, Bd 50 (1985); M. Eisenbeis, Museum und Publikum: Über einige Bedingungen des Museumsbesuchs. Museumskunde, Bd 45 (1980).

2. H.J. Klein, M. Bachmayer: Museum und Öffentlichkeit, Berlin (1981).

3. Återgivet i: V. Scherer: Deutsche Museen: Entstebung und kulturgeschichtliche Bedeutung unserer öffentlichen Kunstsammlungen. Jena (1913).

4. B. Graf, H. Treinen: Besucher im technischen Museum, Berlin (1983).

5. R. Rosenthal, R. Rosnow (eds): Artifact in Behavioral Research, New York/London (1969).

6. H. Treinen: Museen; i: G. Langenbucher $\mathrm{m} f \mathrm{l}$ (utg): Kulturpolitisches Wörterbuch, Stuttgart (1982).

7. H. Treinen; Ansätze zu einer Soziologie des Museumswesens; i: Albrecht $\mathrm{m} \mathrm{fl}$ (utg): Soziologie. Opladen (1973).

8. P. Bourdieu: Die feinen Unterschiede. Frankfurt a M (1984).

9. Jfr emellertid när det gäller gestaltningsmöjligheter: P. Schuck-Wersig och G. Wersig: Die Lust am Schauen oder: Müssen Museen langweilig sein? Berlin (1986).

10. B. Graf, H. Treinen a a (not 4)

11. H. Treinen: Das Museum als Massenmedium Besucherstrukturen, Besucherinteresse und Museumsgestaltung; i: ICOM/CECA (utg), Museumspädagogik: Museumsarchitektur für den 
HEINER TREINEN

70 Besucher. Hannover (1981).

12. K. Berg, M. Kiefer (utg): Massenkommunikation II. Eine Langzeitstudie zur Mediennutzung und Medienbewertung 1964-1982. Frankfurt a M (1982).

13. H. Bonfadelli, V. Saxer: Medienverhalten und Wissensstand: Zur Hypothese der wachsenden Wissenskluft; i: Deutsche Lesegesellschaft (utg): Buch und lesen. Mainz (1978).

14. H. Bonfadelli et al: Jugend und Medien. Frankfurt a M (1986).

15. E: Katz: The Two-Step-Flow of Communication; i: POQ, Vol 21 (1957).

16. Aufermann, Bohrmann, Sülzer (utg):

Gesellschaftliche Kommunikation und Information (1973).

17. H. Treinen: Museumspädagogik und Besucherverhalten: eine empirische Untersuchung zur Benutzung und Wirkung von Ausstellungen; i: Sozialwissenschaftliche Informationen für Unterricht und Studium, Årg 10 (1981).

18. H. Treinen: Kulturökologie; i: UNESCO (utg): Stadtökologie. Köln (1978).

19. H. Treinen a a (not 6).

20. E. Spranger, Vom Bildungswert der Heimatkunde. Stuttgart (1953); A. Lichtwark: Museen als Bildungsstätten; i: Lichtwark: Auswabl aus seinen Schriften, Bd 2. Berlin (1917).

Heiner Treinen innehar lärostolen i socialvetenskaplig metodlära och socialstatistik vid Ruhr-Universität, Bochum. Han har forfattat talrika museologiska och museisociologiska texter.

Adr: Institut für Sozialwissenschaft, Rubr-Universität, Postfach 102148, D-4630 Bochum. 